Dicle Tıp Dergisi / Dicle Medical Journal (2017) 44 (4) : 381-394

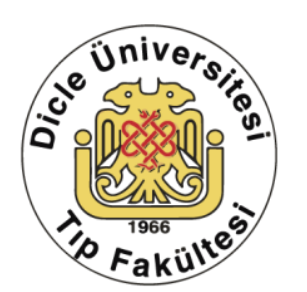

wWW.diclemedj.org

Original Article/Özgün Araştırma

\title{
p-Cymene Based Organometallic Ruthenium(II)-Arene Complexes with Benzaldehyde Derived Thiosemicarbazones: Synthesis, Characterization and Antimicrobial Activity
}

\author{
Murat Yavuz $^{1,2}$, Pelin Köse Yaman³, Nurdan Öztürk ${ }^{4}$, Suna Timur², Elif Subaşı ${ }^{3}$ \\ 1 Chemistry Department, Faculty of Science, Dicle University, 21280 Diyarbakir, Turkey ORCID: 0000-0003-3452-8551 \\ 2 Biochemistry Department, Faculty of Science, Ege University, 35100 Bornova, Izmir, Turkey ORCID: 0000-0002-1981-7577 \\ 3 Chemistry Department, Faculty of Science, Dokuz Eylul University, 35160 Buca, Izmir, Turkey ORCID: 0000-0003-0376-2177 \\ 3 Chemistry Department, Faculty of Science, Dokuz Eylul University, 35160 Buca, Izmir, Turkey ORCID: 0000-0002-4235-9391 \\ 4 Chemistry Division, The Graduate School of Natural and Applied Sciences, Dokuz Eylul Univ. 35160 Buca, Izmir, Turkey ORCID: 0000-0002-9026-6376
}

Received: 20.08.2017; Revised: 29.09.2017; Accepted: 16.10.2017

\begin{abstract}
Objective: Thiosemicarbazone (TSC) containing three new mononuclear ruthenium(II)-arene complexes were synthesized so as to contribute to the development of ruthenium complexes with pharmacologically attracted properties.

Methods: Reactions of the ruthenium(II)-arene dimer $\left[\left\{\mathrm{RuCl}(\mu-\mathrm{Cl})\left(\eta^{6}-p \text {-cymene }\right)\right\}_{2}\right](\mathbf{1})$ with the respective TSC1-3 (1:2 molar ratio) in methanol resulted in $p$-cymene containing new conformationally rigid half-sandwich organometallic ruthenium(II)-arene

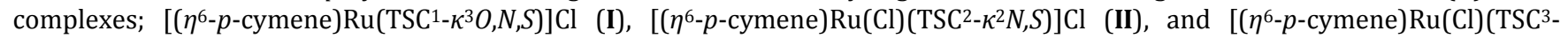
$\left.\left.\kappa^{2} N, S\right)\right] \mathrm{Cl}$ (III). The molecular structures of complexes I, II and III were elucidated on the spectroscopic data obtained by the application of ${ }^{1} \mathrm{H}$ NMR, Fourier transform infrared (FT-IR), UV-vis and elemental analysis techniques. In vitro antimicrobial activities of the synthesized three ruthenium(II)-arene complexes were evaluated using the disc diffusion method.

Results: The spectroscopic data indicated that $\operatorname{TSC}^{1}$ was bounded to the metal as a tridentate ligand with its thione sulfur atom, phenolic oxygen atom and azomethine nitrogen atom in the complex I, while $\mathrm{TSC}^{2}$ and $\mathrm{TSC}^{3}$ were bounded to metal center as bidentate manner through their thione sulfur atom and imine nitrogen $(\mathrm{C}=\mathrm{N})$ atom in the complexes II and III, respectively. The obtained antimicrobial activity results showed that these complexes efficiently inhibit the growth of Gram-positive bacterial strains.

Conclusion: The TSC1-3 containing ruthenium(II)-arene complexes were successfully synthesized and their molecular structures were also determined by the spectroscopic methods. All ruthenium(II)-arene complexes showed higher antibacterial activities against Gram-positive bacterial strains than the Gram-negative ones.
\end{abstract}

Keywords: Half-sandwich Ru(II)-arene complexes, benzaldehyde thiosemicarbazone, p-cymene, antimicrobial activity, clinical isolate.

DOI: $10.5798 /$ dicletip.362482

Yazıșma Adresi / Correspondence: Murat Yavuz, Chemistry Department, Faculty of Science, Dicle University, 21280 Diyarbakir, Turkey e-mail: myavuz@dicle.edu.tr 


\section{Benzaldehitten Türemiş Tiyosemikarbazon İçeren $p$-Simen Temelli Organometalik Rutenyum(II)-Aren Kompleksler: Sentezi, Karakterizasyonu ve Antimikrobiyal Aktivitesi}

\section{Özet}

Amaç: Farmakolojik olarak ilgi çekici özelliklere sahip rutenyum komplekslerinin gelişimine katkıda bulunmak amaciyla tiyosemikarbazon (TSC) içeren üç yeni mononükleer rutenyum(II)-aren kompleksleri sentezlendi.

Yöntemler: Rutenyum(II)-aren dimeri $\left[\left\{\operatorname{RuCl}(\mu-\mathrm{Cl})\left(\eta^{6} \text { - } p \text {-simen }\right)\right\}_{2}\right]$ (1) sirasiyla TSC ${ }^{1-3}$ (1:2 molar oranda) ile metanol içerisindeki reaksiyonu sonucu $p$-simen içeren konformasyonel olarak rijit yarı-sandviç Ru(II)-aren kompleksleri; $\left[\left(\eta^{6}-p\right.\right.$-simen)Ru(TSC $\left.\left.1-\kappa^{3} O, N, S\right)\right] \mathrm{Cl}(\mathbf{I}),\left[\left(\eta^{6}-p\right.\right.$-simen)Ru(Cl)$\left.\left(\mathrm{TSC}^{2}-\kappa^{2} N, S\right)\right] \mathrm{Cl}(\mathbf{I I})$, ve [( $\eta^{6}-p$-simen) $\left.\mathrm{Ru}(\mathrm{Cl})\left(\mathrm{TSC}^{3}-\kappa^{2} N, S\right)\right] \mathrm{Cl}$ (III) bileşikleri sentezlendi. Kompleks I, II ve III'ün moleküler yapıları elementel analiz teknikleri ve ${ }^{1} \mathrm{H}$ NMR, Fourier transform infrared (FT-IR), UV-vis uygulamaları ile elde edilen spektroskopik veriler temelinde aydınlatıldı. Sentezlenen üç rutenyum(II)-aren kompleksinin in vitro antimikrobiyal aktivitesi disk difüzyon metodu ile değerlendirildi.

Bulgular: Spektroskopik veriler TSC $^{1}$ 'in kompleks I'de tiyon sülfür atomu, fenolik oksijen atomu ve azometin azot atomu üzerinden üç-dişli ligant olarak metale bağlanırken, TSC $^{2}$ ve TSC $^{3}$ 'ün kompleks II ve III'te tiyon sülfür atomu ve imin azot $(\mathrm{C}=\mathrm{N})$ atomu üzerinden çift-dişli ligant olarak merkezi metal atomuna bağlandığını ortaya koymuştur. Gözlemlenen antimikrobiyal aktivite sonuçları komplekslerin Gram-pozitif bakteri suşlarının büyümelerini etkin bir biçimde inhibe ettiğini göstermiştir.

Sonuç: TSC ${ }^{1-3}$ içeren yeni mononükleer rutenyum(II)-aren kompleksleri başarılı bir biçimde sentezlendi ve moleküler yapıları spektroskopik yöntemlerle belirlendi. Bütün rutenyum(II)-aren kompleksleri Gram-negatif bakterilerden ziyade Gram-pozitif bakterilere karşı yüksek antimikrobiyal aktivite gösterdi.

Anahtar kelimeler: Yarı-sandviç Ru(II)-aren kompleksler, benzaldehit tiyosemikarbazonlar, $p$-simen, antimikrobiyal aktivite, klinik izolat.

\section{INTRODUCTION}

Thiosemicarbazones (TSCs) are of current interest with respect to their chemotherapeutic properties and biological activity. ${ }^{1}$ These compounds have many applications especially as reagents for the micro-analytical determination. ${ }^{2}$ TSCs have nitrogen and sulfur donors which can coordinate to metal centers. ${ }^{3}$ TSCs and their metal complexes have been extensively researched during recent years, as integration of metals onto TSCs can afford variation or enhancement of their biological activities. ${ }^{4}$

TSCs have useful structural motif that is of the potential to display chemical functionality in biologically active molecules. ${ }^{5}$ TSCs and their metal complexes have many examples of pharmacological applications including antimalarial, antiviral, antiamoebic, antiprotozoal, antibacterial, antifungal and anticancer activities. ${ }^{3-8}$ Their biological activities are considered to play a vital role in biological systems due to the TSCs to chelate with trace metal ions. 8,9 Optimization of these type molecules can result in discovery of new class therapeutic agents. There has been great regard in the chemistry and medicine of organometallic ruthenium(II)-arene complexes as the improvement of effective synthetic precursors. ${ }^{10-12}$ Organometallic ruthenium complexes, especially the half-sandwich arene ruthenium(II) complexes, are thought to be a bright class of antimicrobial and anticancer agents. $^{13}$ The geometry of half-sandwich ruthenium(II) complexes allow a decent formation of new molecules by altering the corresponded arene ring, the chloride group and the chelated ligand. ${ }^{4,15}$ The aim of incorporate organometallic and biological constituents has led to the improvement of new and promising biological active and water soluble molecules. 
In our recent study, TSCs containing halfsandwich ( $\eta^{6}$ - $p$-cymene) ruthenium(II) complex $\left[\left(\eta^{6}-p\right.\right.$-cymene $\left.) \mathrm{RuClTSC}^{N-S}\right] \mathrm{Cl}$ and ruthenium(II) carbonyl complex $\left[\mathrm{Ru}(\mathrm{CO}) \mathrm{Cl}\left(\mathrm{PPh}_{3}\right)_{2} \mathrm{TSC}^{\mathrm{N}-\mathrm{S}}\right]$ were synthesized and their biosensor applications and antimicrobial activity tests were carried out. ${ }^{9}$ The structural characterization and oxygen sensitivity of ruthenium(II) carbonyl complexes were also studied and their antimicrobial activities were determined by our research group. ${ }^{16}$ We reported that arene containing ruthenium(II) complexes show higher antimicrobial activity than the others. In this paper, we present synthesis, characterization and antimicrobial activity of new conformationally stable ruthenium(II)-arene complexes $\quad\left[\left(\eta^{6}-p\right.\right.$ cymene)Ru(TSC $\left.\left.{ }^{1}-\kappa^{3} O, N, S\right)\right] \mathrm{Cl}, \quad(\mathbf{I}) ; \quad\left[\left(\eta^{6}-p-\right.\right.$ cymene) $\left.\mathrm{Ru}(\mathrm{Cl})\left(\mathrm{TSC}^{2}-\kappa^{2} N, S\right)\right] \mathrm{Cl}$, (II) and $\left[\left(\eta^{6}-p-\right.\right.$ cymene) $\left.\mathrm{Ru}(\mathrm{Cl})\left(\mathrm{TSC}^{3}-\kappa^{2} N, S\right)\right] \mathrm{Cl}, \quad$ (III) of benzaldehyde derived mono thiosemicarbazones.

\section{METHODS}

\section{Chemicals and physical measurements}

Reagent grade chemicals and solvents were used in the synthesis of the organometallic ruthenium(II)-arene complexes. $\mathrm{RuCl}_{3} \cdot 3 \mathrm{H}_{2} \mathrm{O}$ and thiosemicarbazide were obtained from Sigma-Aldrich. Silica gel and all used solvents (dichloromethane, ethanol, methanol, petroleum ether) were purchased from Merck. All chemicals used for the syntheses of benzaldehyde derived mono thiosemicarbazones were purchased from Sigma-Aldrich as well. All reactions were carried out under argon by Schlenk technique. Solvents were dried and purified according to standard procedure prior to use.

Proton nuclear magnetic resonance ( ${ }^{1} \mathrm{H}$ NMR) spectra were recorded either on a Varian AS 400 Mercury Plus FT-NMR spectrometer (Varian Inc., Palo Alto, CA, USA) or on a Bruker AVANCE DRX 500 spectrometer (Bruker BioSpin GmbH, Rheinstetten, Germany), operating at $400 \mathrm{MHz}$ and $500 \mathrm{MHz}$ for ${ }^{1} \mathrm{H}$, under ambient conditions by using $\mathrm{CDCl}_{3}$ or DMSO- $d_{6}$ as solvents and tetramethylsilane (TMS) as an internal reference. Electronic spectra were taken with Shimadzu Model 1800 UV-vis spectrophotometer in the range of 200$800 \mathrm{~nm}$. Fourier transform infrared (FT-IR) spectra were recorded using $\mathrm{KBr}$ discs on a Varian 1000 FT spectrophotometer in the range 400-4000 $\mathrm{cm}^{-1}$. Elemental analyses (C, H, $\mathrm{S}$ and $\mathrm{N}$ ) were performed on a LECOCHNS-9320 model elemental analyser by the Scientific and Technological Research Council of Turkey (TUBITAK). The purity of the $\mathrm{TSC}^{\mathrm{n}}(\mathrm{n}=1-3)$ ligands and their organometallic ruthenium(II)arene complexes (I-III) was controlled by thin layer chromatography (TLC) on aluminium plates coated with silica gel $60 \mathrm{~F}_{254}$.

Dichloro( $p$-cymene)ruthenium(II) $\left[\left\{\operatorname{RuCl}(\mu-\mathrm{Cl})\left(\eta^{6}-p \text {-cymene }\right)\right\}_{2}\right] \quad$ (1) (precursor complex) was synthesized following the published method. ${ }^{17}$ TSC $^{1-3}$ ligands were prepared by reducing the Schiff bases of the type reported by Mandal and Chakravarty. ${ }^{18}$

\section{Synthesis of benzaldehyde derived TSC ligands}

$\mathrm{TSC}^{1-3}$ ligands were prepared according to Klayman's et al. ${ }^{19}$ and Scovill's methods. ${ }^{20}$ As a general procedure, a hydrazinecarbothioamide was dissolved in methanol by stirring and refluxing for $30 \mathrm{~min}$. After the addition of corresponding aldehydes; (2-hydroxy-3methoxybenzaldehyde (o-vanillin), 3hydroxybenzaldehyde or 3,4dihydroxybenzaldehyde), the mixture of reaction was refluxed for 4-6 $\mathrm{h}$ in the presence of $2 \mathrm{~mL}$ of $\mathrm{H}_{2} \mathrm{SO}_{4}$. The solvent was evaporated under reduced pressure and the obtained residue was recrystallized using the petroleum ether. Finally, the purified compounds were dried under vacuum and kept for further synthesis. The molecular structures of synthesized 2-hydroxy-3methoxybenzaldehyde thiosemicarbazone $\left(\mathrm{TSC}^{1}\right)$, 3-hydroxybenzaldehyde 
thiosemicarbazone $\left(\mathrm{TSC}^{2}\right)$ and 3,4dihydroxybenzaldehyde thiosemicarbazone $\left(\mathrm{TSC}^{3}\right)$ ligands were illustrated in Figure 1. The synthesis, structural characterization and oxygen sensitivity of the ruthenium(II) carbonyl complexes containing these ligands were previously published by our research group. ${ }^{16}$
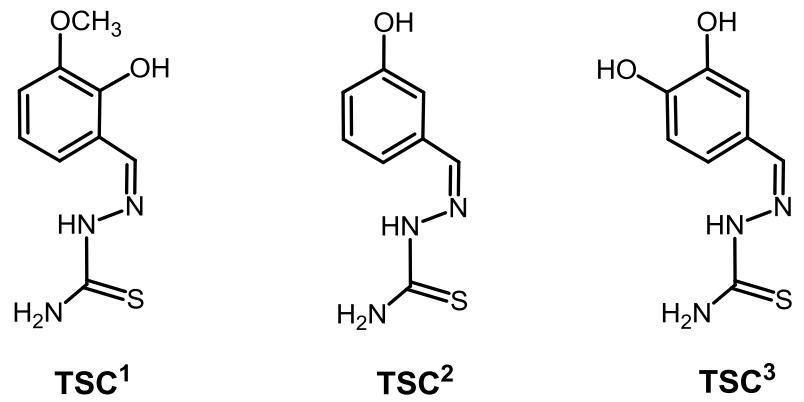

Figure 1. The molecular structure of synthesized TSC ${ }^{1-3}$ ligands.

\section{Characterization data of 2-hydroxy-3- methoxybenzaldehyde thiosemicarbazone (TSC ${ }^{1}$ ).}

Yield: 84\%; Colour: light brown; Analytical data: $\mathrm{C}_{9} \mathrm{H}_{11} \mathrm{~N}_{3} \mathrm{O}_{2} \mathrm{~S}$ required: $\mathrm{C}, 47.99 ; \mathrm{H}, 4.92 ; \mathrm{N}$, 18.65; O, 14.20; S, 14.23. Found: C, 47.87; H, 4.85; N, 18.58; 0, 14.15; S, 14.28\%; FT-IR (v, $\mathrm{KBr}$ pellet, $\mathrm{cm}^{-1}$ ): 3458 (s, asym- $\mathrm{NH}_{2}$ ), 3337 (s, sym- $\left.\mathrm{NH}_{2}\right), 3263(\mathrm{br}, \mathrm{OH}), 3151(\mathrm{~m}, \mathrm{NH}), 1591$ $(\mathrm{s}, \mathrm{C}=\mathrm{N}), 819(\mathrm{~m}, \mathrm{C}=\mathrm{S}), 1053(\mathrm{~m}, \mathrm{CN}, \mathrm{NCN})$, 1254 (s, phenolic $\mathrm{C}-0)$; ${ }^{1} \mathrm{H}$ NMR $(500 \mathrm{MHz}, \delta$, DMSO- $\left.d_{6}, \mathrm{ppm}\right): 11.38(1 \mathrm{H}, \mathrm{s}, \mathrm{N} H), 9.16,(1 \mathrm{H}, \mathrm{br}$ s, $o-\mathrm{OH}), 8.09$ and $7.86\left(2 \mathrm{H}\right.$, both br s,N $\left.H_{2}\right), 8.38$ $(1 \mathrm{H}, \mathrm{s}, H \mathrm{C}=\mathrm{N}), 7.52\left(1 \mathrm{H}, \mathrm{d}, A r-H, 3 J_{\mathrm{H}-\mathrm{H}}=8.7\right)$, $6.95\left(1 \mathrm{H}, \mathrm{d}, \mathrm{Ar}-\mathrm{H}, 3_{\mathrm{H}-\mathrm{H}}=8.7\right), 6.76(1 \mathrm{H}, \mathrm{m}, \mathrm{Ar}-$
$H$ ), $3.80\left(3 \mathrm{H}, \mathrm{s}, \mathrm{OCH}_{3}\right)$ (Figure $\left.2 \mathrm{~A}\right)$; UV-vis (in tetrahydrofuran (THF), $\mathrm{nm}$ ): $\lambda: 324.5$, with identical spectroscopic properties.

\section{Characterization data of 3-hydroxybenzaldehyde thiosemicarbazone (TSC ${ }^{2}$ ).}

Yield: 82\%; Colour: light brown; Analytical data: $\mathrm{C}_{8} \mathrm{H}_{9} \mathrm{~N}_{3} \mathrm{OS}$ required: $\mathrm{C}, 49.21 ; \mathrm{H}, 4.65 ; \mathrm{N}$, 21.52; 0, 8.19; S, 16.42. Found: C, 49.06; $\mathrm{H}$, 4.46; N, 21.20; 0, 8.06; S, 16.25\%; FT-IR ( $v, \mathrm{KBr}$ pellet, $\left.\mathrm{cm}^{-1}\right): 3409$ (m, asym- $\left.\mathrm{NH}_{2}\right), 3276$ (s, sym$\mathrm{NH}_{2}$ ), 3189 (br, OH), 3155 (m, NH), 1593 (s, $\mathrm{C}=\mathrm{N}), 831(\mathrm{~m}, \mathrm{C}=\mathrm{S}), 1062(\mathrm{~m}, \mathrm{CN}, \mathrm{NCN}) ;{ }^{1} \mathrm{H}$ NMR (500 MHz, $\delta$, DMSO-d6, ppm): 11.35 (1H, s, $\mathrm{NH}), 9.51(1 \mathrm{H}, \mathrm{s}, m-\mathrm{OH}), 8.16$ and $7.88(2 \mathrm{H}$, both br s, NH2), $7.95(1 \mathrm{H}, \mathrm{s}, H \mathrm{C}=\mathrm{N}), 7.20(1 \mathrm{H}, \mathrm{s}$, $\operatorname{Ar}-H), 7.17\left(1 \mathrm{H}, \mathrm{d}, \mathrm{Ar}-H,{ }^{3} \mathrm{~J}_{\mathrm{H}-\mathrm{H}}=7.7\right), 7.13(1 \mathrm{H}, \mathrm{d}$, Ar- $\left.H, 3^{3} \mathrm{H}-\mathrm{H}=7.4\right), 6.79(1 \mathrm{H}, \mathrm{m}$, Ar- $H$ ) (Figure 2B); UV-vis (in THF, $\mathrm{nm}$ ): $\lambda: 325$ with identical spectroscopic properties.

\section{Characterization data of 3,4-}

dihydroxybenzaldehyde thiosemicarbazone (TSC ${ }^{3}$ ).

Yield: 86\%; Colour: light red; Analytical data: $\mathrm{C}_{8} \mathrm{H}_{9} \mathrm{~N}_{3} \mathrm{O}_{2} \mathrm{~S}$ required: $\mathrm{C}, 45.49 ; \mathrm{H}, 4.29 ; \mathrm{N}, 19.89$; 0, 15.15; S, 15.18. Found: C, 45.35; H, 4.16; N, 19.76; O, 15.02; S, 15.05\%; FT-IR ( $v$, KBr pellet, $\mathrm{cm}^{-1}$ ): 3466 (s, asym- $\mathrm{NH}_{2}$ ), 3326 (m, sym- $\mathrm{NH}_{2}$ ), 3126 (br, OH), $3181(\mathrm{~m}, \mathrm{~N}-\mathrm{H}), 3181(\mathrm{~s}, \mathrm{~N}-\mathrm{H})$, 1595 (s, C=N), 838 (m, C=S), 1111 (m, CN, NCN); ${ }^{1} \mathrm{H}$ NMR (500 MHz, $\delta$, DMSO- $\left.d_{6}, \mathrm{ppm}\right)$ : $11.20(1 \mathrm{H}$, br s, NH), 9.29 and $9.24(2 \mathrm{H}$, both br $\mathrm{s}, m-$ and $p-\mathrm{OH}), 8.04$ and $7.72(2 \mathrm{H}$, both br s, $\left.\mathrm{NH}_{2}\right), 7.87(1 \mathrm{H}, \mathrm{s}, H \mathrm{C}=\mathrm{N}), 7.16(1 \mathrm{H}, \mathrm{s}, \operatorname{Ar}-H)$, $7.00(1 \mathrm{H}, \mathrm{d}, \mathrm{Ar}-\mathrm{H}, 3 \mathrm{3} \mathrm{H}-\mathrm{H}=8.1), 6.73(1 \mathrm{H}, \mathrm{d}, \mathrm{Ar}-\mathrm{H}$, ${ }^{3} \mathrm{~J}_{\mathrm{H}-\mathrm{H}}=8.1$ ) (Figure 2C); UV-vis (in THF, nm): $\lambda$ : 333 with identical spectroscopic properties. 


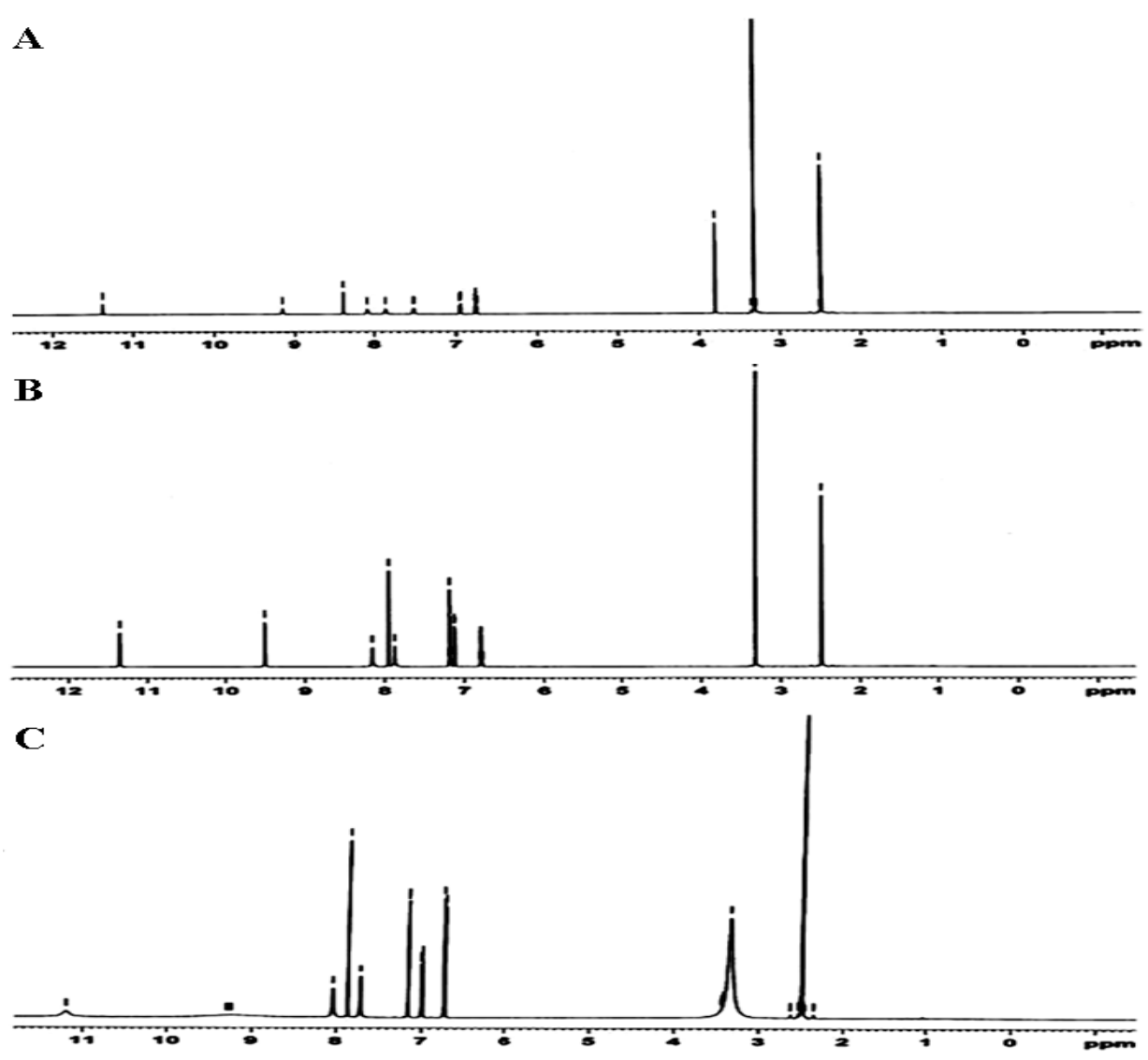

Figure 2. ${ }^{1} \mathrm{H}$ NMR spectra of (A) TSC ${ }^{1}$, (B) TSC ${ }^{2}$ and (C) TSC ${ }^{3}$ ligands (500 MHz, DMSO- $d_{6}$ ).

\section{Synthesis of the complexes}

Complexes I-III were prepared by the reaction of the ruthenium(II)-arene dimeric precursor $\left[\left\{\operatorname{RuCl}(\mu-\mathrm{Cl})\left(\eta^{6}-p \text {-cymene }\right)\right\}_{2}\right] \quad$ (1) with benzaldehyde derived $\mathrm{TSC}^{1-3}$ ligands. The preparation methods were given as a representative example.

\section{[( $\eta^{6}$-p-cymene $\left.) R u\left(T S C^{1}-\kappa^{3} O, N, S\right)\right] C I(I)$.}

Solution of dichloro( $p$-cymene)ruthenium(II) dimer (1) (1224 mg, $2 \mathrm{mmol}$ ) in $25 \mathrm{~mL}$ of methanol was added to a solution of $\operatorname{TSC}^{1}(900$ $\mathrm{mg}$, $4 \mathrm{mmol}$ ) in $50 \mathrm{~mL}$ of methanol. The mixture was refluxed for $6 \mathrm{~h}$ under argon atmosphere with stirring, and then left to cool $30{ }^{\circ} \mathrm{C}$. The solution was condensed to $20 \mathrm{~mL}$ and the compound was then separated with petroleum ether, filtered and dried in vacuum, respectively. Characterization data: Yield: 80\%; Colour: orange; Analytical data:
$\mathrm{C}_{19} \mathrm{H}_{24} \mathrm{ClN}_{3} \mathrm{O}_{2} \mathrm{RuS}$ required: $\mathrm{C}, 46.10 ; \mathrm{H}, 4.89 ; \mathrm{N}$, 8.49; S, 6.48. Found: C, 45.98; H, 4.73; N, 8.41; S, 6.49\%; FT-IR ( $v, \mathrm{KBr}$ pellet, $\mathrm{cm}^{-1}$ ): 3393 (s, asym- $\left.\mathrm{NH}_{2}\right), 3228\left(\mathrm{~s}, \operatorname{sym}-\mathrm{NH}_{2}\right), 3151(\mathrm{~m}, \mathrm{NH})$, $1552(\mathrm{~s}, \mathrm{C}=\mathrm{N}), 778$ (m, C=S), 1065 (m, CN, NCN), 1248 (s, phenolic $\mathrm{C}-0) ;{ }^{1} \mathrm{H}$ NMR $(400 \mathrm{MHz}, \delta$, $\left.\mathrm{CDCl}_{3}, \mathrm{ppm}\right): 11.26(1 \mathrm{H}, \mathrm{br} \mathrm{s}, \mathrm{N} H), 8.52$ and 7.98 $\left(2 \mathrm{H}\right.$, both br s, $\left.\mathrm{NH}_{2}\right), 9.05(1 \mathrm{H}, \mathrm{s}, H \mathrm{C}=\mathrm{N}), 6.72-$ $7.53(3 \mathrm{H}, \mathrm{m}, \mathrm{Ar}-H), 5.42$ and $4.88(2 \mathrm{H}$, both d, $\mathrm{CH},\left(\eta^{6}-p\right.$-cymene), $\left.{ }^{3} \mathrm{~J}_{\mathrm{H}-\mathrm{H}}=5.79\right), 4.80$ and 4.65 $\left(2 \mathrm{H}\right.$, both $\mathrm{d}, \mathrm{CH},\left(\eta^{6}-p\right.$-cymene), $\left.{ }^{3} \mathrm{~J} \mathrm{H}-\mathrm{H}=5.82\right)$, $3.81\left(3 \mathrm{H}, \mathrm{s}, \mathrm{OCH} \mathrm{CH}_{3}\right), 2.63(\mathrm{~m}, 1 \mathrm{H}, \mathrm{CH}$ (methine)), $2.05\left(\mathrm{~s}, 3 \mathrm{H}, \mathrm{CH}_{3}\right), 1.23\left(3 \mathrm{H}, \mathrm{d}, \mathrm{CH}_{3}\left({ }^{i} \mathrm{Pr}\right),{ }^{3} \mathrm{~J}_{\mathrm{H}-\mathrm{H}}=\right.$ 6.82), $1.16\left(3 \mathrm{H}, \mathrm{d}, \mathrm{CH}_{3}\left({ }^{i} \mathrm{Pr}\right),{ }^{3} \mathrm{JH}_{\mathrm{H}-\mathrm{H}}=6.77\right)$; UV-vis (in THF, nm): $\lambda_{1}: 358, \lambda_{2}: 272$.

\section{[( $\eta^{6}$-p-cymene $\left.) R u(C l)\left(\mathrm{TSC}^{2}-\kappa^{2} N, S\right)\right] C l$ (II).}

$\mathrm{TSC}^{2} \quad(845 \mathrm{mg}, 4 \mathrm{mmol})$ and $\left\{\left(\eta^{6}-p-\right.\right.$ cymene) $\mathrm{RuCl}_{2}(\mu-\mathrm{Cl})_{2}(\mathbf{1})$ precursor $(1224 \mathrm{mg}$, $2 \mathrm{mmol}$ ) were used for synthesis of complex II. 
Characterization data: Yield: 82\%; Colour: orange; Analytical data: $\mathrm{C}_{18} \mathrm{H}_{23} \mathrm{Cl}_{2} \mathrm{~N}_{3} \mathrm{ORuS}$ required: $\mathrm{C}, 43.11 ; \mathrm{H}, 4.62 ; \mathrm{N}, 8.38 ; \mathrm{S}, 6.39$. Found: C, 43.25; H, 4.75; N, 8.51; S, 6.39\%; FTIR ( $v, \mathrm{KBr}$ pellet, $\left.\mathrm{cm}^{-1}\right): 3395\left(\mathrm{~m}\right.$, asym- $\left.\mathrm{NH}_{2}\right)$, 3224 (s, sym- $\left.\mathrm{NH}_{2}\right), 3155$ (m, NH), 1563 (s, $\mathrm{C}=\mathrm{N}), 816(\mathrm{~m}, \mathrm{C}=\mathrm{S}), 1120(\mathrm{~m}, \mathrm{CN}, \mathrm{NCN}) ;{ }^{1} \mathrm{H}$ NMR (400 MHz, $\left.\delta, \mathrm{CDCl}_{3}, \mathrm{ppm}\right): 11.37(1 \mathrm{H}, \mathrm{s}$, $\mathrm{N} H), 9.53(1 \mathrm{H}, \mathrm{s}, \mathrm{m}-\mathrm{OH}), 8.38$ and $7.91(2 \mathrm{H}$, both br s, NH2), $8.56(1 \mathrm{H}, \mathrm{s}, H \mathrm{C}=\mathrm{N}), 6.70-7.87$ $(4 \mathrm{H}, \mathrm{m}, \mathrm{Ar}-\mathrm{H}), 5.82$ and $5.76(2 \mathrm{H}$, both $\mathrm{d}, \mathrm{CH}$, $\left(\eta^{6}\right.$-p-cymene), $\left.{ }^{3} \mathrm{~J}_{\mathrm{H}-\mathrm{H}}=5.66\right), 5.42$ and $4.86(2 \mathrm{H}$, both $\mathrm{d}, \mathrm{CH},\left(\eta^{6}-p\right.$-cymene), $\left.{ }^{3} \mathrm{H} \mathrm{H}-\mathrm{H}=5.80\right), 2.68(\mathrm{~m}$, $1 \mathrm{H}, \mathrm{CH}$ (methine)), $2.12\left(\mathrm{~s}, 3 \mathrm{H}, \mathrm{CH}_{3}\right), 1.24(3 \mathrm{H}$, d, $\left.\mathrm{CH}_{3}\left({ }^{i} \mathrm{Pr}\right),{ }^{3} J_{\mathrm{H}-\mathrm{H}}=6.81\right), 1.15\left(3 \mathrm{H}, \mathrm{d}, \mathrm{CH}_{3}\left({ }^{i} \mathrm{Pr}\right)\right.$, $3 J_{\mathrm{H}-\mathrm{H}}=6.84$ ); UV-vis (in THF, nm): $\lambda_{1}: 330, \lambda_{2}$ : 253.

\section{[\{( $\eta^{6}-p$-cymene $\left.) R u(C I)\left(T_{S C}^{3}-\kappa^{2} N, S\right)\right] C I(I I I)$.}

$\mathrm{TSC}^{3}$ (781 $\left.\mathrm{mg}, 4 \mathrm{mmol}\right)$ and $\left\{\left(\eta^{6}-p\right.\right.$ cymene) $\mathrm{RuCl}_{2}(\mu-\mathrm{Cl})_{2}$ (1) precursor (1224 mg, $2 \mathrm{mmol}$ ) and were used for synthesis of complex III. Characterization data: Yield: 80\%; Colour: orange; Analytical data: $\mathrm{C}_{18} \mathrm{H}_{23} \mathrm{Cl}_{2} \mathrm{~N}_{3} \mathrm{O}_{2} \mathrm{RuS}$ required: $\mathrm{C}, 41.78 ; \mathrm{H}, 4.48 ; \mathrm{N}$, 8.12; S, 6.20. Found: C, 41.53; H, 4.32; N, 8.27; S, 6.31\%; FT-IR ( $v, \mathrm{KBr}$ pellet, $\left.\mathrm{cm}^{-1}\right): 3390$ (s, $\left.\operatorname{asym}-\mathrm{NH}_{2}\right), 3230\left(\mathrm{~m}, \operatorname{sym}-\mathrm{NH}_{2}\right), 3181(\mathrm{~m}, \mathrm{NH})$, $1566(\mathrm{~s}, \mathrm{C}=\mathrm{N}), 825$ (m, C=S), 1120 (m, CN, $\mathrm{NCN}$ ); ${ }^{1} \mathrm{H}$ NMR (400 MHz, $\left.\delta, \mathrm{CDCl}_{3}, \mathrm{ppm}\right): 11.28$ $(1 \mathrm{H}$, br s, NH), 9.32 and $9.28(2 \mathrm{H}$, both br s, $m$ and $p-\mathrm{OH}), 8.18$ and $7.75(2 \mathrm{H}$, both br $\mathrm{s}, \mathrm{NH} 2)$, $8.57(1 \mathrm{H}, \mathrm{s}, H \mathrm{C}=\mathrm{N}), 6.74-7.92(3 \mathrm{H}, \mathrm{m}, \mathrm{Ar}-H)$, 5.98 and $5.84\left(2 \mathrm{H}\right.$, both $\mathrm{d}, \mathrm{CH},\left(\eta^{6}\right.$-p-cymene), $\left.3 \int_{\mathrm{H}-\mathrm{H}}=5.78\right), 5.28$ and $4.94\left(2 \mathrm{H}\right.$, both $\mathrm{d}, \mathrm{CH},\left(\eta^{6-}\right.$ $p$-cymene), $\left.3 J_{\mathrm{H}-\mathrm{H}}=5.83\right), 2.57(\mathrm{~m}, 1 \mathrm{H}, \mathrm{CH}$ (methine)), $2.15\left(\mathrm{~s}, 3 \mathrm{H}, \mathrm{CH}_{3}\right), 1.22\left(3 \mathrm{H}, \mathrm{d}, \mathrm{CH}_{3}\right.$ $\left.\left({ }^{i} \mathrm{Pr}\right),{ }^{3} J_{\mathrm{H}-\mathrm{H}}=6.74\right), 1.18\left(3 \mathrm{H}, \mathrm{d}, \mathrm{CH}_{3}\left({ }^{i} \mathrm{Pr}\right), 33_{\mathrm{H}-\mathrm{H}}=\right.$ 6.82); UV-vis (in THF, nm): $\lambda_{1}: 342, \lambda_{2}: 267$.

\section{Test for antimicrobial activity}

In this study, standard microorganisms or clinically isolated strains were used. They were as follows: There were clinically isolated Pseudomonas aeruginosa, Streptococcus agalactiae and Staphylococcus aureus strains,
Enterobacter cloacae ATCC 23355, Streptococcus pyogenes ATCC 19615, Escherichia coli ATCC 25922, Staphylococcus aureus ATCC 25923, Bacillus subtilis ATCC 11774, Pseudomonas aeruginosa ATCC 27853, and one yeast Candida albicans ATCC 10231. The reference strains from the American Type Culture Collection (ATCC) were purchased from LGC Standards GmbH (Wesel, Germany). Three clinically isolated strains were kindly obtained from the Faculty of Medicine, Microbiology Department at the Dicle University (Diyarbakir, Turkey). Amoxycillin/clavulanic acid discs (2:1) (AMC, $30 \mu \mathrm{g}$ ), ofloxacin discs (OFX, $5 \mu \mathrm{g}$ ), erythromycin discs (E, $15 \mu \mathrm{g})$, imipenem discs (IMP, $10 \mu \mathrm{g}$ ) (all from Oxoid) and nystatin discs $(\mathrm{N}, 60 \mu \mathrm{g})$ (Sigma) were used as positive controls.

In vitro antibacterial activities of the halfsandwich organometallic ruthenium(II)-arene complexes (I-III) were investigated by the disc diffusion method according to our previously described method based upon the NCCLS (National Committee for Clinical Laboratory Standards).9,16 The bacterial strains were inoculated into $25 \mathrm{~mL}$ of Nutrient Broth (Oxoid) medium in an orbital shaker at 200 rpm for 4 to $6 \mathrm{~h}$ until a turbidity of 0.5 McFarland $\left(1 \times 10^{8} \mathrm{CFU} / \mathrm{mL}\right)$ was reached. Final inoculum on Nutrient Agar (NA, Merck) plates was adjusted to $5 \times 10^{5} \mathrm{CFU} / \mathrm{mL}$. Yeast $C$. albicans ATCC 10231 was inoculated into 25 $\mathrm{mL}$ of Sabouraud Dextrose Broth (Oxoid) in an orbital shaker at $200 \mathrm{rpm}$ for 8 to $10 \mathrm{~h}$ until a turbidity of 0.5 McFarland was provided. The final inoculum on Sabouraud Dextrose Agar (Merck) plates was adjusted to $5 \times 10^{5}$ $\mathrm{CFU} / \mathrm{mL}$. Filter paper discs $(6 \mathrm{~mm}$ diameter, Oxoid) were impregnated with 10, 15 and 20 $\mu \mathrm{L}$ of stock solutions $(5 \mathrm{mg} / \mathrm{mL}$ in methanol/dichloromethane (2:8)), and were then dried under sterile condition for $4 \mathrm{~h}$. Prepared discs were settled on the inoculated agar surfaces. Solvent system (methanol/dichloromethane (2:8) $20 \mu \mathrm{L}$ ) was 
used as a negative control. These plates were incubated at $37^{\circ} \mathrm{C}$ for $24 \mathrm{~h}$ for bacteria and 48 $\mathrm{h}$ for yeast. All attempts were carried out twice and the antimicrobial activity was presented as the mean of inhibition diameters ( $\mathrm{mm}$ ) formed by complexes (I-III).

\section{RESULTS AND DISCUSSION}

\section{Synthesis and Characterization}

As shown in Scheme 1, compounds I-III were synthesized by the reaction of $\operatorname{dichloro}(p$ cymene) ruthenium(II) dimer (1) with the respective $\mathrm{TSC}^{1-3}$ in a 1:2 molar ratio in methanol. All ruthenium(II)-arene halfsandwich complexes were characterized by using analytical and spectroscopic methods.

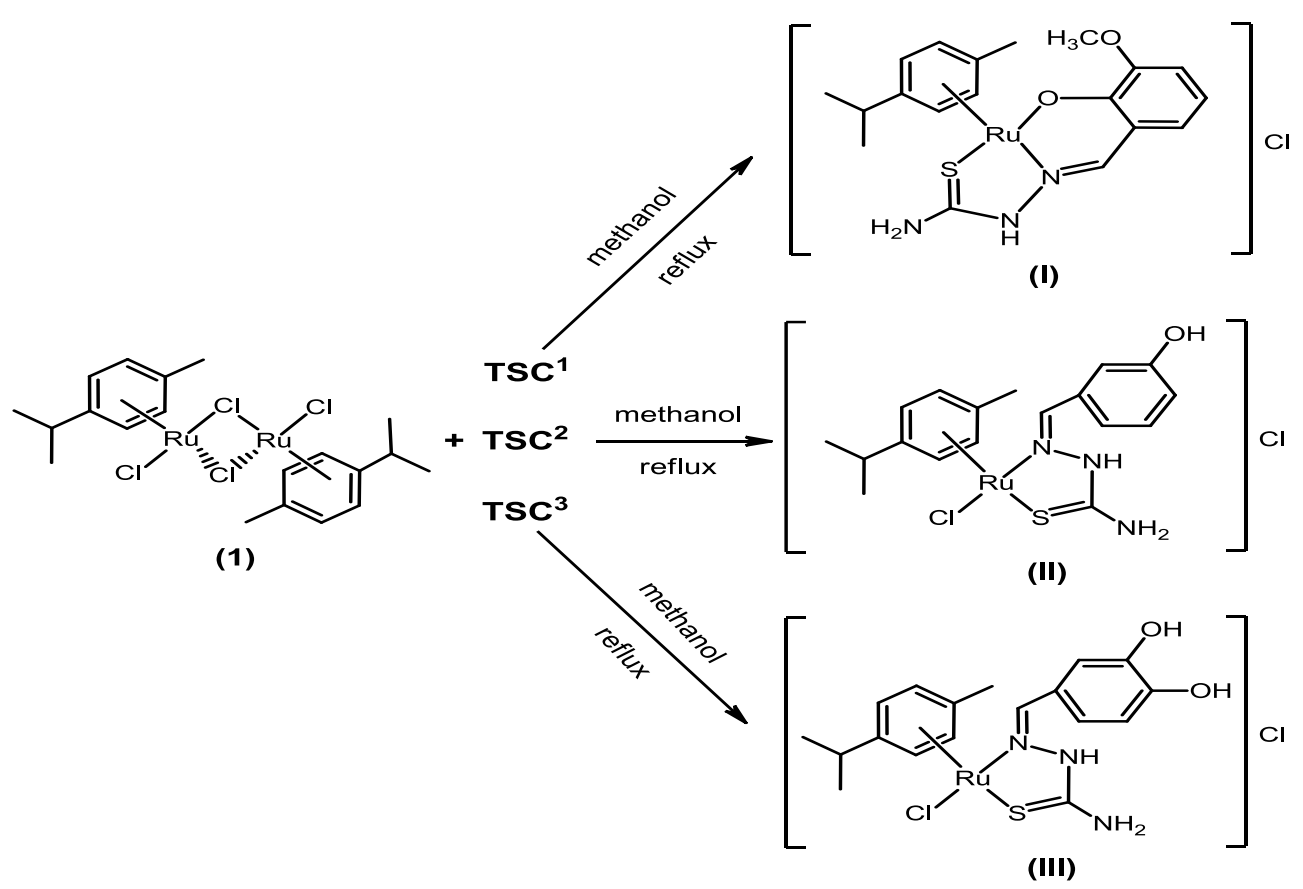

Scheme 1. Synthesis of the organometallic ruthenium(II)-arene complexes (I-III).

The analytical data for I-III were given in the Materials and Methods section. The obtained analytical data for the synthesized ruthenium(II)-arene complexes corresponded to suggested formula. The complexes I-III were isolated in moderate yields up to $80 \%$. The organometallic ruthenium(II)-arene halfsandwich complexes were completely resistant to both air and light. All complexes (I-III) were quite soluble in dimethyl sulfoxide, dichloromethane and chloroform.
Infrared spectra. TSCs are very versatile ligands and adopt various binding modes with transition metal ions by bonding through hydrazinic terminal nitrogen and sulfur atoms. They can exist in the two tautomeric forms as either neutral thione form or anionic form after deprotonation in order to coordinate to the metal center, as shown in Figure 3. The FT-IR spectra of all complexes approve that all of the TSC $^{1-3}$ ligands coordinated as thione form in IIII. The principal stretching frequencies of ruthenium(II)-arene complexes I-III were given in the Materials and Methods section. 


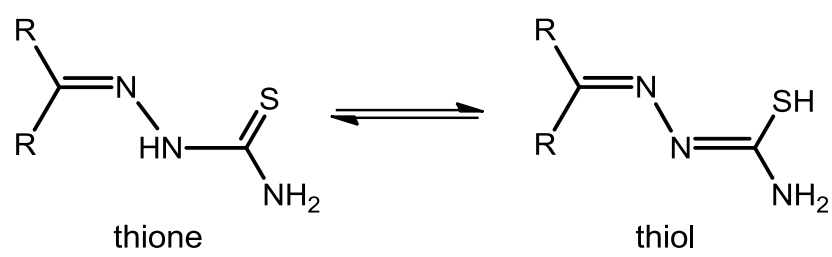

Figure 3. Tautomeric forms of thiosemicarbazone (TSC).

The peaks observed between 3276-3337 and $3409-3466 \mathrm{~cm}^{-1}$ regions in the FT-IR spectra of the $\mathrm{TSC}^{1-3}$ ligands were assigned to symmetric and asymmetric stretching frequencies of terminal $\mathrm{NH}_{2}$ groups, respectively. These bands were observed in the spectra of the complexes as well, indicating non-involvement of this group in coordination. A sharp band at 3151, 3155 and $3181 \mathrm{~cm}^{-1}$ for complexes I to III, respectively, related to $\mathrm{v}(\mathrm{N}-\mathrm{H})$ of $-\mathrm{NH}-\mathrm{N}=\mathrm{C}$ moiety was presented both in the complex and free ligand spectra. ${ }^{21}$

Coordination through the imine nitrogen was inferred by variation of the absorption bands between the complex and free TSC. The $\mathrm{C}=\mathrm{N}$ stretching bands observed for the free TSC ${ }^{1}$, $\mathrm{TSC}^{2}$ and $\mathrm{TSC}^{3}$ ligands at 1591, 1593 and 1595 $\mathrm{cm}^{-1}$, respectively, which were shifted to lower frequencies in the spectra of the complexes and thus alters $v_{(\mathrm{C}=\mathrm{N})}$ to $1552 \mathrm{~cm}^{-1}$ for II, $1563 \mathrm{~cm}^{-1}$ for II and $1566 \mathrm{~cm}^{-1}$ for III after coordination via the imine nitrogen of ligands to ruthenium(II) metal center. The $\mathrm{v}_{(\mathrm{N}-\mathrm{N})}$ bands of the free $\mathrm{TSC}^{1}, \mathrm{TSC}^{2}$ and $\mathrm{TSC}^{3}$ were observed at 1053, 1062 and $1111 \mathrm{~cm}^{-1}$, respectively. In the spectra of the complexes, the altered frequencies of these bands at $1065 \mathrm{~cm}^{-1}$ for I, $1120 \mathrm{~cm}^{-1}$ for II and III provided evidence for coordination via imine nitrogen. ${ }^{16,22}$ The absorptions bands of $\mathrm{TSC}^{1}$, $\mathrm{TSC}^{2}$ and $\mathrm{TSC}^{3}$ at 819,831 and $838 \mathrm{~cm}^{-1}$, respectively, belonging to $v(C=S)$, were observed in the lower frequency region in the spectra of the complexes at 778 $\mathrm{cm}^{-1}$ for II, $816 \mathrm{~cm}^{-1}$ for II and $825 \mathrm{~cm}^{-1}$ for III. This downward shift $\left(13-41 \mathrm{~cm}^{-1}\right)$ in the complexes suggested the coordination of thione sulfur atom.
A sharp band due to phenolic -C-O absorption was observed at $1254 \mathrm{~cm}^{-1}$ in free TSC 1 . During the complex formation, this band shifted to lower frequency $\left(1248 \mathrm{~cm}^{-1}\right)$, exhibiting coordination of $\mathrm{TSC}^{1}$ via the phenolic oxygen. ${ }^{16,23}$ At the same time, it is verified that the disappearance of the observed broad band at $3263 \mathrm{~cm}^{-1}$ in free $\mathrm{TSC}^{1}$ due to phenolic $\mathrm{v}_{(\mathrm{OH})}$ in complex $\mathbf{I}$.

FT-IR spectra of the organometallic ruthenium(II)-arene complexes demonstrated that $\mathrm{TSC}^{2}$ and $\mathrm{TSC}^{3}$ ligands were bonded as bidentate to ruthenium(II) via imine $\mathrm{N}$ and thione $\mathrm{S}$ atoms, whereas $\mathrm{TSC}^{1}$ ligand was coordinated as a tridentate to ruthenium(II) via imine $\mathrm{N}$, phenolic $\mathrm{O}$ and thione $\mathrm{S}$ atoms. The $\mathrm{U}(\mathrm{M}-\mathrm{N})$ stretching bands are promoted by coordination of the azomethine $\mathrm{N}$. The formation of $\mathrm{Ru}(\mathrm{II})-\mathrm{O}$ and $\mathrm{Ru}(\mathrm{II})-\mathrm{N}$ bonds is further supported by the appearance of the medium intensity bands at $518-526 \mathrm{~cm}^{-1}$ and the low frequency region band at $439 \mathrm{~cm}^{-1}$, respectively, in the spectra of the chelates. ${ }^{24,25}$

${ }^{1}$ H NMR spectra. The molecular structures of synthesized new stable half-sandwich organometallic ruthenium(II)-arene complexes (I-III) were confirmed by ${ }^{1} \mathrm{H}$ NMR spectroscopy. The ${ }^{1} \mathrm{H}$ NMR spectral results obtained for $\mathrm{TSC}^{1}, \mathrm{TSC}^{2}$ and $\mathrm{TSC}^{3}$ ligands in DMSO- $d_{6}$ and their ruthenium(II)-arene complexes (I-III) in $\mathrm{CDCl}_{3}$, together with the assignments, were given in Materials and Methods section.

Phenolic proton signals of the free ligands were observed at $9.16 \mathrm{ppm}$ for TSC $1,9.51 \mathrm{ppm}$ for $\mathrm{TSC}^{2}$ and the two signals at 9.24 and $9.29 \mathrm{ppm}$ for $\mathrm{TSC}^{3}$, respectively. The observed singlet peak based upon $-\mathrm{OH}$ proton in the spectrum of free $\mathrm{TSC}^{1}$ vanished in the spectra of complex I. ${ }^{16}$ This observation was proven coordination to ruthenium through phenolic oxygen atom at complex I. In the spectra of complexes II and III, the signals were assigned at $9.53 \mathrm{ppm}$ for II, the two broad signals at 9.28 and $9.32 \mathrm{ppm}$ for 
III due to phenolic hydroxyl groups. The signals for the methoxy protons were seen near 3.80 ppm region both $\mathrm{TSC}^{1}$ ligand and its complex (I).

In the spectra of complexes (I-III), sharp singlets were appeared at 9.05 (I), 8.56 (II) and $8.57 \mathrm{ppm}$ (III), and these peaks were assigned to imine protons $(-\mathrm{HC}=\mathrm{N})$. A downfield shift was observed for these signals compared to the free TSC ${ }^{1-3}$ ligands (TSC ${ }^{1}$, TSC $^{2}$ and TSC $^{3}$ at 8.38, 7.95 and 7.87 ppm, respectively) upon coordination to ruthenium, suggesting coordination of the metal to the azomethine nitrogen atom as the signal becomes more deshielded in each case. This is usually revealed for similar arene-ruthenium(II)-TSCs as well. ${ }^{12,13,26}$ For $\mathrm{TSC}^{1-3}$ ligands, the $\mathrm{NH}_{2}$ group generated two distinct singlets between 8.048.16 and 7.72-7.88 ppm. This pattern is to be expected as a result of the $\mathrm{C}-\mathrm{N}$ bond possessing some $\pi$ character via the mesomeric effect, as the protons are magnetically nonequivalent. ${ }^{14,26}$ This results in hindered rotation about this bond which is common in thioamides. ${ }^{14}$

The multiplets observed in the region around $\delta$ 6.73-7.52 ppm in all the listed complexes were assigned to the aromatic protons of the phenyl groups of the free $\mathrm{TSC}^{1-3}$ ligands. The hydrazinic $\mathrm{NH}$ protons of free ligands which resonated at 11.38, 11.35 and $11.20 \mathrm{ppm}$ for TSC ${ }^{1}$, TSC $^{2}$ and TSC $^{3}$, respectively, were observed at 11.26 for I, 11.37 for II and 11.28 ppm for III with slight shifts in the spectra of the complexes.

In the ${ }^{1} \mathrm{H}$ NMR spectra of I-III all showed that the $\mathrm{TSC}^{1-3}$ ligands were in neutral thione form (evidenced by the presence of the $-\mathrm{NH}-$ protons). The methyl substituents of the isopropyl group were appeared as two welldefined doublets, which additionally verified the loss of symmetry of two unequal methyl groups, in the aliphatic region of the spectra. The methyl protons were resonated at 1.16 and
1.23 ppm for I, 1.15 and 1.24 ppm for II and 1.18 and 1.22 ppm for III. Four doublets were observed for the arene-ring and were found in the region of 4.65-5.42 ppm for I, 4.86-5.82 ppm for II and 4.94-5.98 ppm for III. The disappearance of symmetry was approved by the presence of a set of two doublets explain the protons of the $p$-cymene rings. The methyls of the isopropyl were appeared as two welldefined doublets in the aliphatic region of the NMR spectra, which also approved the absence of symmetry as the two methyls were unequal. The disappearance of symmetry of the $p$ cymene rings in all cases proves that coordination modes of I-III were identical.12,13,26

Electronic spectra. In the electronic spectra of the complexes I-III were recorded in THF, and the two absorption regions were observed at the $253-272 \mathrm{~nm}$ and $330-358 \mathrm{~nm}$, respectively.

Complexes I to III the first bands region (272, 253 and $267 \mathrm{~nm}$, respectively) could be corresponding to $\mathrm{Ru}(4 \mathrm{~d} \pi) \rightarrow \pi^{*}$ (imine) (MLCT) transition. The bands below $272 \mathrm{~nm}$ were due to intra-ligand transitions taking place within TSC orbitals. These bands were presented in the UV spectra of the TSCs as well, but at a pretty lower wavelength, approving the coordination of the TSCs to ruthenium. The UV spectra pattern of I-III suggested the presence of an octahedral environment around the metal. 27

The most likely assignment for the second band region was due to the $n \rightarrow \pi$ and/or $\pi \rightarrow \pi^{*}$ transitions. The ground state of areneruthenium(II)-TSCs was ${ }^{1} \mathrm{~A}_{1 \mathrm{~g}}$, stem from the $\mathrm{t}^{6}{ }_{2 \mathrm{~g}}$ configuration in an $\mathrm{O}_{\mathrm{h}}$ surrounding. Excited states according to the $\mathrm{t}^{5} \mathrm{ge}^{\mathrm{g}} \mathrm{g}$ configuration were ${ }^{3} \mathrm{~T}_{1 \mathrm{~g}},{ }^{3} \mathrm{~T}_{2 \mathrm{~g}}{ }^{1} \mathrm{~T}_{1 \mathrm{~g}}$, and ${ }^{1} \mathrm{~T}_{2 \mathrm{~g}}$. Accordingly, four bands due to the transitions ${ }^{1} \mathrm{~A}_{1 \mathrm{~g}} \rightarrow{ }^{3} \mathrm{~T}_{1 \mathrm{~g}}$, ${ }^{1} \mathrm{~A}_{1 \mathrm{~g}} \rightarrow{ }^{3} \mathrm{~T}_{2 \mathrm{~g}}, \quad{ }^{1} \mathrm{~A}_{1 \mathrm{~g}} \rightarrow{ }^{1} \mathrm{~T}_{1 \mathrm{~g}}$, and ${ }^{1} \mathrm{~A}_{1 \mathrm{~g}} \rightarrow{ }^{1} \mathrm{~T}_{2 \mathrm{~g}}$ were most likely, in order of increasing energy. ${ }^{16}$ 


\section{Antimicrobial activity of organometallic ruthenium(II)-arene complexes}

In the present study, the in vitro antimicrobial properties of ruthenium(II)-arene complexes I, II and III were studied using a disc diffusion assay approved by NCCLS against ten test microorganisms. Some of them were clinically isolated S. aureus and control strain $S$. aureus ATCC 25923 strains, pyogenic bacteria known to play a significant role in invasive skin diseases including deep and superficial infections such as impetigo, cellulitis, folliculitis, subcutaneous abscesses, infected ulcers and wounds. ${ }^{28}$ C. albicans was also chosen for this study since it is an infection of the yeast fungus, which occurs on the surface of the tongue and inside the mucus of the cheeks. S. aureus and C. albicans are often co-isolated in cases of biofilm associated infections. However, the literature on the interactions between these pathogens is limited. ${ }^{29}$

The TSC containing three new mononuclear ruthenium(II)-arene complexes were displayed compromising antibacterial activities against Gram-positive bacterial strains. Table 1 exhibits the evaluation of the antibacterial activities of the standard antibiotics versus tested microorganisms. The results indicate that the used bacterial strains can be evaluated as susceptible for OFX and IPM antibiotics. Nystatin shows $22 \mathrm{~mm}$ inhibition zone against C. albicans ATCC 10231. The antimicrobial activities of organometallic ruthenium(II)arene complexes are presented in Table 1. None of the complexes (I-III) show activity to Gram-negative bacterial strains and the yeast fungus C. albicans ATCC 10231 at the assessed concentrations. The complexes I, II and III exhibit reasonable antimicrobial activities against Gram-positive S. aureus ATCC 25923, S. pyogenes ATCC 19615, B. subtilis ATCC 11774 and clinical isolates $S$. agalactiae and S. aureus. The data conceded that the standard ATCC strains of Gram-positive bacteria were more susceptible than Gram-negative ones. These results were also confirmed by early works. ${ }^{9,16}$ It has been suggested that the mechanism of the antimicrobial effects incorporates the inhibition of various cellular procedures, followed by an increase in plasma membrane permeability and in the end ion leakage from the cells. ${ }^{30}$ In other respects, the variation of susceptibility between Gram-negative and Gram-positive bacteria could be as regards to their essential properties that are related to the permeability of their cell surface to the conformationally stable half-sandwich ruthenium(II)-arene complexes (I-III). ${ }^{9,30}$ 
Table 1. Antimicrobial activity of complexes (I-III) and standard antibiotics against different test microorganisms.

\begin{tabular}{|c|c|c|c|c|c|c|c|c|c|c|c|c|c|c|}
\hline \multirow{4}{*}{ Test microorganisms } & \multicolumn{14}{|c|}{ Zones of inhibition (mm) } \\
\hline & \multicolumn{9}{|c|}{ Samples ${ }^{b}$} & \multicolumn{5}{|c|}{ Standard antibiotics ${ }^{b}$} \\
\hline & $\mathbf{I}$ & & & II & & & III & & & OFX & AMC & IPM & $\mathrm{E}$ & $\mathrm{N}$ \\
\hline & 50 & 75 & 100 & 50 & 75 & 100 & 50 & 75 & 100 & 5 & 30 & 10 & 15 & 60 \\
\hline $\begin{array}{l}\text { Staphylococcus aureus } \\
\text { ATCC } 25923\end{array}$ & 9 & 11 & 12 & 9 & 11 & 13 & 9 & 12 & 15 & 22 & 30 & 40 & 20 & $\mathrm{nt}$ \\
\hline Staphylococcus aureus ${ }^{\mathrm{a}}$ & 9 & 11 & 12 & 10 & 12 & 13 & 10 & 11 & 14 & 22 & 16 & 38 & 20 & $\mathrm{nt}$ \\
\hline $\begin{array}{l}\text { Bacillus subtilis } \\
\text { ATCC } 11774\end{array}$ & 8 & 10 & 11 & 12 & 14 & 16 & 9 & 11 & 14 & 26 & 28 & 44 & 38 & $\mathrm{nt}$ \\
\hline $\begin{array}{l}\text { Streptococcus pyogenes } \\
\text { ATCC } 19615\end{array}$ & 8 & 10 & 12 & 10 & 12 & 14 & 9 & 11 & 13 & 16 & 24 & 28 & 24 & nt \\
\hline Streptococcus agalactiae ${ }^{\mathrm{b}}$ & 8 & 10 & 12 & 9 & 12 & 14 & 8 & 12 & 13 & 22 & 32 & 34 & 28 & $\mathrm{nt}$ \\
\hline $\begin{array}{l}\text { Escherichia coli } \\
\text { ATCC } 25922\end{array}$ & - & - & - & - & - & - & - & - & - & 26 & 16 & 20 & 10 & $\mathrm{nt}$ \\
\hline $\begin{array}{l}\text { Enterobacter cloacae } \\
\text { ATCC } 23355\end{array}$ & - & - & - & - & - & - & - & - & - & 28 & 18 & 22 & - & $\mathrm{nt}$ \\
\hline $\begin{array}{l}\text { Pseudomonas aeruginosa } \\
\text { ATCC } 27853\end{array}$ & - & - & - & - & - & - & - & - & - & 14 & - & 22 & - & nt \\
\hline Pseudomonas aeruginosa $a^{\mathrm{a}}$ & - & - & - & - & - & - & - & - & - & 22 & - & 24 & - & $\mathrm{nt}$ \\
\hline $\begin{array}{l}\text { Candida albicans } \\
\text { ATCC } 10231\end{array}$ & - & - & - & - & - & - & - & - & - & $\mathrm{nt}$ & $\mathrm{nt}$ & nt & $\mathrm{nt}$ & 22 \\
\hline
\end{tabular}

At $100 \mu \mathrm{g}$ concentration, complexes (I-III) were found to be highly effective opposed to $S$. aureus ATCC 25923, S. pyogenes ATCC 19615, B. subtilis ATCC 11774 and clinical isolates $S$. aureus and $S$. agalactiae with a zone diameter from 11 to 16 . The complex III $(100 \mu \mathrm{g} /$ disc $)$ demonstrated effective antimicrobial activity with 14 and $15 \mathrm{~mm}$ inhibition zone diameter against clinically isolated S. aureus (Figure 4A) and control strain S. aureus ATCC 25923 strains, respectively. Further, the complex III exhibited the best antibacterial activity $(16 \mathrm{~mm}$ inhibition zone at $100 \mu \mathrm{g} /$ disc) against $B$. subtilis ATCC 11774 (Figure 4B) compared with the activity of the tested antibiotics. It was finally observed that the tested compounds did not have any antimicrobial activities versus Gram-negative bacteria and yeast. Complexes (I-III) exhibited moderated antimicrobial activities versus Gram-positive bacterial strains. 

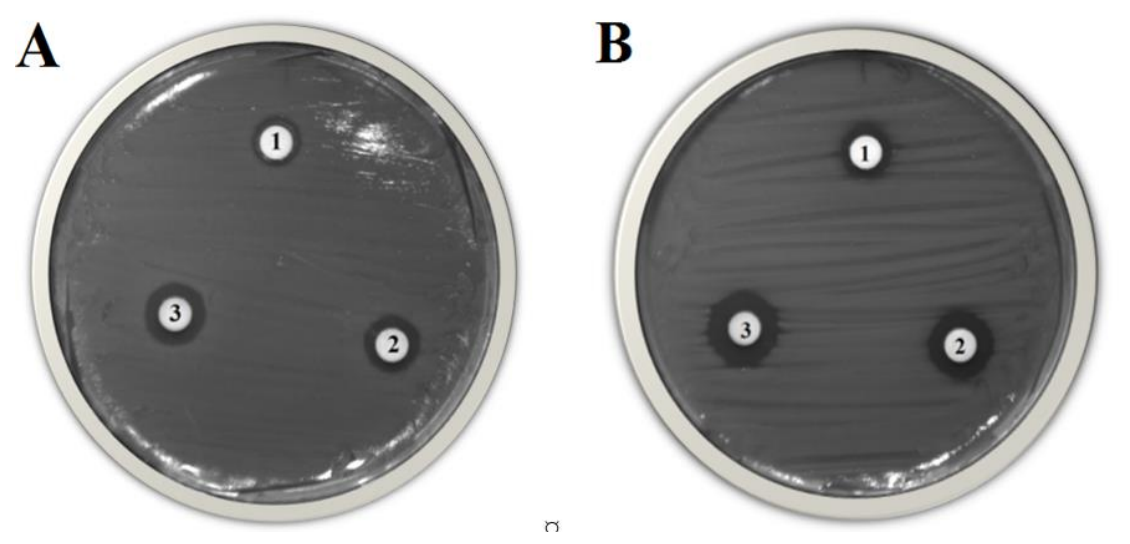

Figure 4. Antimicrobial activity of organometallic ruthenium(II)-arene complex (III) against the used (A) clinical isolate $S$. aureus and (B) indicator microorganism B. subtilis ATCC 11774 (1: 50 $\mu \mathrm{g} /$ disc, 2: $75 \mu \mathrm{g} /$ disc and 3: $100 \mu \mathrm{g} /$ disc).

\section{CONCLUSION}

The synthesis and spectral characterization of benzaldehyde derived TSCs and their stable half-sandwich ruthenium(II)-arene complexes (I-III) and their antibacterial activities were described in this paper. According to the spectroscopic studies TSC $^{1}$ was bonded to ruthenium as a tridentate ligand via the imine $\mathrm{N}$, phenolic $\mathrm{O}$, and thionyl $\mathrm{S}$ donors in $\mathbf{I}$, while TSC $^{2}$ and TSC $^{3}$ were bound to the central metal through the imine $\mathrm{N}$ and thiocarbonyl $\mathrm{S}$ donors in a bidentate mode in II and III. As for the spectral data, all evidences indicated that the TSCs remain neutral form (as proved by the existence of the $\mathrm{NH}$ protons). The in vitro antimicrobial activity studies demonstrated that organometallic ruthenium(II)-arene halfsandwich complexes I-III were efficient in preventing the growth of Gram-positive bacterial strains.

Declaration of Conflicting Interests: The authors declare that they have no conflict of interest.

Financial Disclosure: This work was financially supported by Dokuz Eylul University Scientific Research Project as a project No: 2015.KB.FEN.018.

\section{REFERENCES}

1. Klayman DL, Scovill JP, Bartosevich JF, Bruce J. 2Acetylpyridine thiosemicarbazones. 5. 1-[1-(2Pyridyl)ethyl]-3-thiosemicarbazides as potential antimalarial agents. J Med Chem. 1983;26:35-9. https://doi.org/10.1021/jm00355a008

2. Atalay T, Akgemci EG. Thermodynamic studies of some complexes of 2-benzoylpyridine 4-phenyl-3thiosemicarbazone. Turk J Chem. 1998;22:123-7.

3. Beraldo H, Gambino D. The wide pharmacological versatility of semicarbazones, thiosemicarbozones and their metal complexes. Mini-Rev Med Chem. 2004; 4: 31-9. https://doi.org/10.2174/1389557043487484

4. Garcia-Tojal J, Garcia-Orad A, Serra JL, et al. Synthesis and spectroscopic properties of copper(II) complexes derived from thiophene-2-carbaldehyde thiosemicarbazone. Structure and biological activity of $\left[\mathrm{Cu}\left(\mathrm{C}_{6} \mathrm{H}_{6} \mathrm{~N}_{3} \mathrm{~S}_{2}\right)_{2}\right]$. J Inorg Biochem. 1999;75:45-54. https://doi.org/10.1016/S0162-0134(99)00031-8

5. Haraguchi SK, Silva AA, Vidotti GJ, et al. Antitrypanosomal activity of novel benzaldehydethiosemicarbazone derivatives from kaurenoic acid. Molecules. 2011;16:1166-80.

https://doi.org/10.3390/molecules16021166

6. Dimmock JR, McColl JM, Wonkol SL, Thayer RS, Hancock DS. Evaluation of the thiosemicarbazones of some aryl alkyl ketones and related compounds for anticonvulsant activities. Eur J Med Chem. 1991;26: 529-34.

https:/ / doi.org/ 10.1016/ 0223-5234(91)90148-Ci 
7. Sharma S, Athar F, Maurya MR, Azam, A. Copper(II) complexes with substituted thiosemicarbazones of thiophene-2-carboxaldehyde: Synthesis, characterization and antiamoebic activity against E. histolytica. EurJ Med Chem. 2005;40:1414-19.

https:/ / doi.org/ 10.1016/j.ejmech.2005.05.013

8. Singh S, Bharti N, Mohapatra PP. Chemistry and biology of synthetic and naturally occurring antiamoebic agents. Chem Rev. 2009;109:1900-47. https://doi.org/10.1021/cr068217k

9. Yildirim H, Guler E, Yavuz M, et al. Ruthenium (II) complexes of thiosemicarbazone: Synthesis, biosensor applications and evaluation as antimicrobial agents. Mater Sci Eng C. 2014;44:1-8.

https://doi.org/10.1016/j.msec.2014.08.007

10. Castarlenas R, Vovard C, Fischmeister C, Dixneuf PH. Allenylidene-to-indenylidene rearrangement in arene-ruthenium complexes: A key step to highly active catalysts for olefin metathesis reactions. J Am Chem Soc. 2006;128:4079-89.

https:/ / doi.org/ 10.1021/ja0579762

11. Pampaloni G. Aromatic hydrocarbons as ligands. Recent advances in the synthesis, the reactivity and the applications of bis $\left(\eta^{6}\right.$-arene $)$ complexes. Coord Chem Rev. 2010;254:402-19.

https:/ / doi.org/ 10.1016/ j.ccr.2009.05.014

12. Raja MU, Sindhuja E, Ramesh R. Arene ruthenium(II) $p$-chloroacetophenone phenylthiosemicarbazone complex mediated transfer hydrogenation of ketones. Inorg Chem Commun. 2010;13:1321-4.

https://doi.org/10.1016/j.inoche.2010.07.026

13. Stringer T, Therrien B, Hendricks DT, Guzgay H, Smith GS. Mono- and dinuclear ( $\eta^{6}$-arene) ruthenium(II) benzaldehyde thiosemicarbazone complexes: Synthesis, characterization and cytotoxicity. Inorg Chem Commun. 2011;14:956-60.

https://doi.org/10.1016/j.inoche.2011.03.041

14. Beckford F, Dourth D, Shaloski Jr M, et al. Halfsandwich ruthenium-arene complexes with thiosemicarbazones: Synthesis and biological evaluation of $\left[\left(\eta^{6}-p\right.\right.$-cymene $) \mathrm{Ru}($ piperonal thiosemicarbazones)Cl]Cl complexes. J Inorg Biochem. 2011;105:1019-29.

https://doi.org/10.1016/j.jinorgbio.2011.04.008

15. Allardyce CS, Dorcier A, Scolaro C, Dyson PJ. Development of organometallic (organo-transition metal) pharmaceuticals. Appl Organomet Chem. 2005;19:1-10. https://doi.org/10.1002/aoc.725

16. Ozturk N, Yaman PK, Yavuz M, Oter O, Timur S, Subasi E. Synthesis, structural characterization, oxygen sensitivity, and antimicrobial activity of ruthenium(II) carbonyl complexes with thiosemicarbazones. J Coord Chem. 2014;67:2688-700.

https:/ / doi.org/ 10.1080/ 00958972.2014.948433

17. Bennett MA, Huang TN, Matheson TW, Smith AK. $\left(\eta^{6-}\right.$ Hexamethylbenzene)ruthenium complexes. Inorg Synth. 1982;21:74-8. https:/ / doi.org/ 10.1002/ 9780470132524.ch16

18. Mandal SK, Chakravarty AR. Arene ruthenium complexes of $\mathrm{N} \mathrm{N}^{\prime}$ - and $\mathrm{N}, \mathrm{O}$-donor schiff base ligands: An X-ray structure of [ $\left(\eta^{6}\right.$ - $p$-cymene $) \mathrm{RuCl}\left(\mathrm{C}_{5}, \mathrm{H}_{4} \mathrm{~N}-2\right.$ $\left.\mathrm{CH}=\mathrm{NC}_{6} \mathrm{H}_{4}-p-\mathrm{Me}\right) \mathrm{Cl} \cdot \mathrm{C} 6 \mathrm{H} 6 \cdot \mathrm{H}_{2} \mathrm{O}$. Polyhedron. 1992;11: 823-7.

https://doi.org/10.1016/S02775387(00)86017-9

19. Klayman DL, Bartosevich JF, Griffin TS, Mason CJ, Scovill JP. 2-Acetylpyridine thiosemicarbazones. 1. A new class of potential antimalarial agents. J Med Chem. 1979;22:855-62.

https://doi.org/10.1021/jm00193a020

20. Scovill JP. A facile synthesis of thiosemicarbazides and thiosemicarbazones by the transamination of 4methyl-4-phenyl-3-thiosemicarbazide. Phosphorus, Sulfur Silicon Relat Elem. 1991;60:15-9. https://doi.org/10.1080/10426509108233920

21. Sampath K, Sathiyaraj S, Raja G, Jayabalakrishnan C. Mixed ligand ruthenium(III) complexes of benzaldehyde 4-methyl-3-thiosemicarbazones with triphenylphosphine/triphenylarsine co-ligands: Synthesis, DNA binding, DNA cleavage, antioxidative and cytotoxic activity. J Mol Struct. 2013;1046:82-91. https://doi.org/10.1016/j.molstruc.2013.04.051

22. Manimaran A, Jayabalakrishnan C. DNA-binding, catalytic oxidation, C-C coupling reactions and antibacterial activities of binuclear $\mathrm{Ru}(\mathrm{II})$ thiosemicarbazone complexes: Synthesis and spectral characterization. J Adv Res. 2012;3:233-43.

https://doi.org/10.1016/j.jare.2011.07.005

23. Natarajan K, Poddar RK, Agarwala U. Mixed complexes of ruthenium(III) and ruthenium(II) with triphenylphosphine or triphenylarsine and other ligands. J Inorg Nucl Chem. 1977;39:431-5. https://doi.org/10.1016/0022-1902(77)80056-0

24. Manivannan S, Prabhakaran R, Balasubramanian KP, Dhanabal V, Karvembu R, Chinnusamy V. Synthesis, spectral, electrochemical and catalytic studies of new $\mathrm{Ru}(\mathrm{III})$ tetradentate Schiff base complexes. Appl Organomet Chem. 2007;21:952-7. https:/ / doi.org/ 10.1002/ aoc.1318 
25. Kamalesu S, Swarnalatha K, Subramanian R, Muralidharan K, Gomathi S. Polypyridyl-hydrazone based Ruthenium(II) complexes: Spectral and computaional analysis. Inorg Chim Acta. 2017;461:35-44. https://doi.org/10.1016/j.ica.2017.01.029

26. Beckford FA, Leblanc G, Thessing J, et al. Organometallic ruthenium complexes with thiosemicarbazone ligands: Synthesis, structure and cytotoxicity of $\left[\left(\eta \sigma_{6}-p\right.\right.$-cymene $\left.) \mathrm{Ru}(\mathrm{NS}) \mathrm{Cl}\right]+(\mathrm{NS}=9-$ anthraldehyde thiosemicarbazones. Inorg Chem Commun. 2009;12:1094-8.

https://doi.org/10.1016/j.inoche.2009.08.034

27. Sivagamasundari $M$, Ramesh R. Luminescent property and catalytic activity of $\mathrm{Ru}(\mathrm{II})$ carbonyl complexes containing $\mathrm{N}, \mathrm{O}$ donor of 2-hydroxy-1naphthylideneimines. Spectrochim Acta Part A. 2007; 66:427-33. https://doi.org/10.1016/j.saa.2006.03.017
28. Krishna S, Miller LS. Host-pathogen interactions between the skin and Staphylococcus aureus. Curr Opin Microbiol. 2012;15:28-35.

https:/ / doi.org/ 10.1016/ j.mib.2011.11.003

29. Schlecht LM, Peters BM, Krom BP, et al. Systemic Staphylococcus aureus infection mediated by Candida albicans hyphal invasion of mucosal tissue. Microbiology. 2015;161:168-81. https:/ / doi.org/ 10.1099/ mic.0.083485-0

30. Walsh SE, Maillard JY, Russel AD, Catrenich CE, Charbonneau DL, Bartolo RG. Activity and mechanisms of action of selected biocidal agents on Gram-positive and -negative bacteria. J Appl Microbiol. 2003;94:240-7. https://doi.org/10.1046/j.1365-2672.2003.01825.x 